ACTA UNIVERSITATIS NICOLAI COPER NICI

\title{
WĄTPLIWOŚCI I KRYTYCZNE POSTAWY PRZEDSIĘBIORSTW TSL WOBEC STOSOWANIA ZASAD SPOŁECZNEJ ODPOWIEDZIALNOŚCI NA PODSTAWIE WYNIKÓW BADAŃ EMPIRYCZNYCH
}

Z a r y s t r e ś c i. W artykule podjęto problematykę wątpliwości i krytycznej postawy przedsiębiorstw wobec społecznej odpowiedzialności. Rozważania oparto na przykładzie przedsiębiorstw sektora TSL. Artykuł podzielono na dwie zasadnicze części. W pierwszej części dokonano przeglądu literatury wraz z ustosunkowaniem się do zidentyfikowanych problemów. Celem tej części było wskazanie, jakie wątpliwości i jakie krytyczne uwagi są przedstawiane w przypadku społecznej odpowiedzialności. W części drugiej przywołano wyniki badań empirycznych, które posłużyły do określenia przyczyn obiekcji względem społecznej odpowiedzialności wśród przedsiębiorstw sektora TSL.

S ł o w a k 1 u c z o w e: społeczna odpowiedzialność, etyka, sektor TSL.

K l a s y fik a c j J E L: M14, L9.

\section{WSTĘP}

Społeczna odpowiedzialność niewątpliwe jest dzisiaj tendencją globalną. Komisja Europejska przyjęła, że przedsiębiorstwo zachowuje się w sposób społecznie odpowiedzialny, kiedy dobrowolnie uwzględnia problematykę społeczną i ekologiczną w swojej działalności gospodarczej oraz w stosunkach ze swoimi interesariuszami. Większość przedsiębiorstw rozumie jej istotę, jest przekonana co do słuszności jej założeń i widzi zasadność ich realizowania, czego wyrazem są konkretne aktywności w obszarach zdefinio-

\footnotetext{
* Adres do korespondencji: Izabela Dembińska, Uniwersytet Szczeciński, WZiEU, ul. Cukrowa 8, 71-004 Szczecin, e-mail: izabela.dembinska@wzieu.pl.

(C) 2015 Uniwersytet Mikołaja Kopernika. All rights reserved. http://www.aunc.ekonomia.umk.pl
} 
wanych w normie serii 26 000. Przesłanki takiej postawy są różne. Ale są również przedsiębiorstwa, niezależnie od rodzaju działalności, jaką się zajmują, które zgłaszają wątpliwości wobec różnych aspektów społecznej odpowiedzialności. Są też takie, które świadomie i jednoznacznie przyjmują postawę krytyczną. Najczęściej są to przedstawiciele sektora małych i średnich przedsiębiorstw. Twierdzenie to potwierdza podejście wobec społecznej odpowiedzialności zaobserwowane wśród małych i średnich przedsiębiorstw sektora TSL. Celem rozważań jest pokazanie, w oparciu o wyniki badań empirycznych, postaw przedsiębiorstw sektora TSL, wyrażających obiekcje i krytykę wobec społecznej odpowiedzialności. Jest to kontynuacja dyskusji, podjętej na konferencji „Logistyka społeczna” w roku 2014, w której scharakteryzowano ogólnie ujęte postawy i zachowania przedsiębiorstw TSL wobec społecznej odpowiedzialności.

\section{WĄTPLIWOŚCI I KRYTYKA SPOŁECZNEJ ODPOWIEDZIALNOŚCI - PRZEGLĄD LITERATURY}

Jak zauważa Rok (2013), termin „społeczna odpowiedzialność biznesu” ma charakter wartościujący. Określając, że dana firma jest społecznie odpowiedzialna, jednocześnie dokonuje się swoistej, pozytywnej oceny. I odwrotnie - twierdzenie, że firma nie jest społecznie odpowiedzialna, sugeruje pejoratywny wydźwięk. Raczej oczywiste założenie, że każda firma chce być dobrze postrzegana, może wskazywać powszechną i masową chęć wypełniania zasad społecznej odpowiedzialności. W rzeczywistości społeczna odpowiedzialność dzieli przedsiębiorstwa, na te, które zaangażowały się w przedsięwzięcia społecznie odpowiedzialne, oraz te, które zgłaszają wobec nich różne obiekcje, a nawet przyjmują postawę jednoznacznie krytyczną.

Krytyka idei społecznej odpowiedzialności pojawiła się już na początku lat sześćdziesiątych XX wieku za sprawą wątpliwości wobec sensu aplikowania koncepcji społecznej odpowiedzialności w działalności przedsiębiorstwa, głoszonych przez Friedmana. Został on nawet powszechnie uznany za twórcę podejścia krytycznego do koncepcji społecznej odpowiedzialności. Twierdził (Friedman, 2002, 1970), że ,jest jedna i tylko jedna społeczna odpowiedzialność biznesu - wykorzystać swoje zasoby i angażować się w działania mające na celu zwiększenie zysków, tak długo, jak długo pozostaje się w ramach reguł gry, angażuje się w otwartej i wolnej konkurencji bez podstępu lub oszustwa". Przekonywał, że przedsiębiorstwo ponosi odpowiedzialność za maksymalizację wartości dla właścicieli poprzez zarabianie jak najwięcej pieniędzy, i że jest to ich moralną powinnością. Niemoralne jest natomiast stawianie celów społecznych i ekologicznych ponad zysk. 
We friedmanowską retorykę wpisuje się współcześnie wielu ekonomistów. Sternberg (1994) wyraża opinię, że wykorzystanie zasobów przedsiębiorstw do celów niezwiązanych z działalnością gospodarczą jest nieuzasadnione. Podobnie uważa Karnani (2010) w swoim artykule opublikowanym w Wall Street Journal. Stwierdza, że działanie na rzecz ogółu nie jest obowiązkiem czy powinnością przedsiębiorstwa. Zauważa, że publicznie przedstawiane przez przedsiębiorstwa przesłanki przedsięwzięć społecznie odpowiedzialnych są fałszywe. Prawdziwy powód przyjmowania postawy społecznie odpowiedzialnej jest prozaiczny - maksymalizacja zysku. Społeczna odpowiedzialność jest wykorzystywana jako skuteczne narzędzie działań marketingowych.

Fleming i Jones (2013) nazywają społeczną odpowiedzialność „,swoistym alibi dla biznesu". Co więcej, uważają, że się skończyła się, zanim tak naprawdę się zaczęła, ponieważ nie przyniosła żadnych ważnych zmian w gospodarce. Te same argumenty przeciwko społecznej odpowiedzialności można znaleźć w artykule Crooka (2005), który ukazał się w 2005 roku, w specjalnym numerze The Economist, poświęconym wyłącznie społecznej odpowiedzialności. Społeczną odpowiedzialność nazywa „licencją na ukrycie" i wskazuje, że stosowanie jej zasad przynosi jedynie kosmetyczne zmiany.

Wyraźnie deklaratywny charakter, manipulacyjny przekaz i nieszczerość społecznej odpowiedzialności wytykają Laufer (2003), Roberts (2003), Sims i Brinkmann (2003). Teoretyczny charakter, oderwanie od realiów codzienności działalności gospodarczej zarzucają m.in. Basu i Palazzo (2008), Boiral (2007), oraz Khan, Munir i Willmott (2007).

Henderson (2001) nazywa społeczną odpowiedzialność „błędną cnotą”, stwierdzając, że społeczna odpowiedzialność wymaga dobrowolnego przyjęcia przez przedsiębiorców szerszych celów, stosowania złożonych procedur i bardziej wymagających standardów, a to wszystko może osłabić parametry ekonomiczne przedsiębiorstwa. Uważa, że społeczna odpowiedzialność wywołuje nadmierną presję na przedsiębiorstwa i grozi zbytnim uzależnieniem efektywnej alokacji zasobów od zewnętrznej ingerencji.

Wskazani autorzy są reprezentacją, niewątpliwie, szerszego grona. Przytoczenie większej liczby opinii wyrażających wątpliwości i krytycyzm względem społecznej odpowiedzialności, ze względu na ograniczoną objętość opracowania, jest trudne. Dlatego, na podstawie rewizji współczesnej literatury przedmiotu, można dokonać pewnego podsumowania poglądów:

1. Podstawową wątpliwością jest pytanie, czy przedsiębiorstwa w ogóle powinny zajmować się społeczną odpowiedzialnością? Czy istota działalności przedsiębiorstwa, cel, dla którego przedsiębiorstwo funkcjonuje 
na rynku, nie ulegają dyskretnej delimitacji? Wydaje się, że nie ma takiego zagrożenia. Nadal oczywiste jest, że istotą działalności przedsiębiorstwa jest wypełniane funkcji produkcyjnej czy usługowej, w zależności od profilu biznesowego, zaś pierwotnym celem funkcjonowania jest zysk. Działania społeczne nie są realizowane jako działania z obszaru core biznes. Wyznaczają raczej kryteria, jakimi przedsiębiorstwo może się kierować, realizując swoje podstawowe zadania. Poza tym rozszerzają zakres i wprowadzają nowe konteksty relacji z otoczeniem, z interesariuszami.

Kwestia, czy przedsiębiorstwa powinny zajmować się społeczną odpowiedzialnością czy też nie, również wydaje się być jasna. Cały czas podkreśla się dobrowolny charakter społecznej odpowiedzialności. Nie ma żadnych uregulować prawnych, które nakazywałyby implementację społecznej odpowiedzialności. Nie ma norm z tego zakresu, które są obligatoryjne. Problemem jest jedynie to, czy traktować społeczną odpowiedzialność jako powinność, nieformalną konieczność czy modę. Inaczej mówiąc, jaką postawę przyjmuje przedsiębiorstwo wobec społecznej odpowiedzialności, co oczywiście wiąże się z motywami tej postawy.

2. Zastanawiając się nad tym, czy społeczną odpowiedzialność traktować jako powinność czy nieformalną konieczność, można stwierdzić, że:

- powinność jest związana $\mathrm{z}$ odpowiedzialnością dobrowolną i przejawia się postawą wkładu;

- nieformalna konieczność jest związana z odpowiedzialnością narzuconą i wymuszoną i może przejawiać się postawą oporu, obowiązku lub reakcji.

Jak można argumentować powinność bycia społecznie odpowiedzialnym? Prowadzenie działalności gospodarczej przedsiębiorstwa oznacza, że jest ona włączana w pewną zastaną rzeczywistość, która stanowi bardzo często złożony układ zdarzeń, procesów i relacji, zachodzących w należących do niej przedmiotach oraz między nimi. W układzie tym realizują się i są realizowane różne wartości przedmiotowe i osobowe. W taką rzeczywistość, mającą już ukształtowaną postać i strukturę, ingeruje przedsiębiorstwo, prowadząc działalność gospodarczą. Każda ingerencja przedsiębiorstwa zawsze jest mniejszym lub większym naruszeniem jej istniejącego ładu, które skutkuje jakimiś zmianami - pozytywnymi i negatywnymi. Bilans tych zmian, to znaczy, które z nich przeważają, zależy od formy i siły ingerencji, czego podstawą jest świadomość przedsiębiorstwa w zakresie tej ingerencji. Nie zachodzi ingerencja tylko z pozytywnymi następstwami. Inaczej mówiąc, zawsze 
będą zachodzić jakieś zmiany negatywne. Taka sytuacja tworzy przyczynowo-skutkową odpowiedzialność przedsiębiorstwa za swoje gospodarcze działania i decyzje. Niewątpliwie, poczucie powinności w tym kontekście wynika z poczucia winy, a co za tym idzie - pytanie, czy przedsiębiorstwa podejmowałyby działania społeczne bez żadnych przesłanek, gdyby nie czuły się winne za swoje negatywne oddziaływanie na rzeczywistość, w której prowadzą działalność gospodarczą, wydaje się być retoryczne. Idąc tym tokiem wywodu, pojawia się problem proporcjonalności odpowiedzialności do wielkości negatywnych skutków działalności gospodarczej przedsiębiorstwa. Można by założyć zależność wprost proporcjonalną, ale żeby mogło to w praktyce funkcjonować, należałoby stworzyć listę negatywnych oddziaływań przedsiębiorstwa na społeczne otoczenie wraz ze wskazaniem, że w związku z wystąpieniem danego oddziaływania należy zrobić to czy tamto. Innymi słowy, należałoby skodyfikować listę negatywnych oddziaływań przedsiębiorstwa w zakresie realizowanych w zamian działań społecznych. A to raczej jest trudne do wykonania, choćby ze względu na złożoność oddziaływań.

3. W kontekście typologii postaw wyłania się pewna wątpliwość - czy można kwalifikować przedsiębiorstwa na odpowiedzialne i nieodpowiedzialne społecznie w systemie zero-jedynkowym, tj. spełnia warunek nie spełnia warunku? Mówi się bowiem ,przedsiębiorstwo społecznie odpowiedzialne", bez wskazywania na poziom tej odpowiedzialności. To może sugerować podejrzenie, że wystarczy zrobić cokolwiek, by być uznanym za przedsiębiorstwo społecznie odpowiedzialne. Jakie są zatem minimalne ramy kwalifikowalności postawy przedsiębiorstwa jako społecznie odpowiedzialnej? Pytanie jest tym trudniejsze, jeśli przywoła się dobrowolny charakter społecznej odpowiedzialności.

4. Wątpliwości wokół społecznej odpowiedzialności sprowadzają się również do postrzegania jej w aspekcie „myślenia życzeniowego”. U podłoża takiego postrzegania leży brak przekonania o jej skuteczności. Trudno się z takim myśleniem zgodzić, ponieważ zasady i działania społeczne, jak pokazuje praktyka, mają charakter realny. Zupełnie innym problemem jest umiejętność ich realizacji. I tu można zgodzić się z kolejnym zarzutem, że kadra menedżerska nie zawsze jest wyposażona w odpowiednie kompetencje, by prowadzić firmę według kanonu społecznej odpowiedzialności, i że czasami te działania są intuicyjne, co może rzutować na trafność decyzji. Niemniej, nie jest to argument na tyle ważny, by występować przeciwko społecznej odpowiedzialności. Można oczywiście polemizować, czy dobre chęci są wystarczające. Jak- 
kolwiek, należy spodziewać się, że upowszechnianie aktywności społecznej doprowadzi w niedługim czasie do wyodrębnienia w strukturze organizacyjnej przedsiębiorstw osobnego stanowiska menedżerskiego, odpowiedzialnego za sprawy społecznej odpowiedzialności.

5. Bardzo często pod dyskusję poddaje się kwestię, kto, tak naprawdę, jest odpowiedzialny? Czy poprawne jest sformułowanie „biznes odpowiedzialny” tudzież „przedsiębiorstwo odpowiedzialne”? Punktem wyjścia jest w tym przypadku rozumowanie friedmanowską argumentacją. M. Friedman tkwił przy stanowisku, że jedynie ludzie mogą być odpowiedzialni, ponieważ ani biznes, ani przedsiębiorstwo nie są osobami i mają jedynie sztuczną, abstrakcyjną odpowiedzialność. Argumentacja ta wydaje się być słuszna, ponieważ to ludzie odpowiadają za swoje działania i decyzje. W związku z tym można przyjąć, że sformułowanie społeczna odpowiedzialność przedsiębiorstwa czy biznesu, to skrót myślowy, który absolutnie nie zwalnia ludzi od odpowiedzialności. Jednocześnie, nie ma potrzeby przeprowadzania rewolucji pojęciowej, by tylko doprecyzować, że to właśnie ludzie są nośnikiem odpowiedzialności. Jednakże, zgadzając się, że odpowiedzialność leży w gestii ludzi, pojawia się kolejna wątpliwość - czy wszyscy pracownicy przedsiębiorstwa są odpowiedzialni za negatywne oddziaływanie przedsiębiorstwa na społeczne otoczenie, czy odpowiedzialność powinna dotyczyć tylko właściciela czy głównych zarządzających? Wszakże to oni zarządzają działaniami oraz podejmują i aprobują decyzje podejmowane w przedsiębiorstwie. Wydaje się, że nie można całkowicie przerzucić odpowiedzialności na właściciela czy zarządzających, bo to oznaczałoby, że pracownicy realizują swoje zadania, nie mając żadnego wpływu na ich przebieg i ich efekty. Wszyscy pracownicy przedsiębiorstwa, łącznie z właścicielem i zarządzającymi, powinni przyjmować postawę społecznie odpowiedzialną, przy czym właściciel i menedżerzy zarządzający powinni pełnić rolę przewodnią.

6. Przeciwnicy społecznej odpowiedzialności podkreślają, że intencje przedsiębiorstw, które podejmują działania społeczne, nie są szczere. Są zafałszowane bądź pozorne. Wskazują, że przedsiębiorstwa stosują społeczną odpowiedzialność jedynie w celach marketingowych, w dodatku w sposób świadomie wyrachowany, objawiając w ten sposób swoją podwójną moralność. Zarzuca się, że gdyby działania społecznej odpowiedzialności nie były opłacalne, przedsiębiorstwa nie podejmowałby się ich. Przyznać trzeba, że działania społeczne dobrze sprawdzają się w roli narzędzi public relations i, już wcześniej stwierdzono, nie należy tego upatrywać jako czegoś złego. O ile osiągane są efekty społeczne, nie ma 
potrzeby zabraniać przedsiębiorstwom wykorzystywania społecznej odpowiedzialności również do innych celów. A rozstrzyganie kwestii podwójnej moralności można rozpocząć od wątpliwości, czy w ogóle biznes jest nacechowany moralnymi pobudkami. Obranie stanowiska w tym sporze zależy od interpretacji, co jest właściwe, a co nie. To z kolei jest determinowane przyjętym systemem wartości, który, jak wiadomo, może być różny, w zależności od kontekstu, miejsca, czasu itp.

7. Często, w dyskusjach krytycznych o społecznej odpowiedzialność, przywołuje się wątek kosztowy. Twierdzi się, że społeczna odpowiedzialność zbyt dużo przedsiębiorstwo kosztuje. Kosztowne jest nie tylko wprowadzanie strategii społecznej odpowiedzialności w obszar funkcjonalny przedsiębiorstwa, ale przede wszystkim jej bieżąca realizacja. W związku z tym wskazuje się na problem sprzeczności z celem minimalizacji kosztów. Inny problem, jaki się w tym przypadku przywołuje dotyczy konkurowania. Porównuje się możliwości konkurencyjne przedsiębiorstwa, które podejmuje działania społeczne, a tym samym ponosi z tego tytułu koszty, z przedsiębiorstwem, które nie angażuje się w społeczną odpowiedzialność. W tym kontekście społeczną odpowiedzialność upatruje się jako czynnik ograniczający konkurencyjność przedsiębiorstwa. Kontrargumentem na takie zarzuty może być fakt, że obecnie pole konkurowania jest bardzo szerokie, nie ogranicza się wyłącznie do kosztów. W tym polu coraz większe znaczenie, jak pokazuje praktyka firm europejskich i światowych, zaczyna odgrywać kultura organizacyjna. To pozwala myśleć o społecznej odpowiedzialności jako o czynniku konkurowania. Nie da się zaprzeczyć, że działania realizowane w ramach społecznej odpowiedzialności są nośnikiem kosztów, ale należy zastanawiać się na tym, co można zrobić, by dzięki tym działaniom uzyskiwać przewagę konkurencyjną. Podkreślić trzeba, że świadomość klientów w zakresie społecznej odpowiedzialności również staje się coraz większa. W konsekwencji tego to, czy przedsiębiorstwo realizuje cele społecznej odpowiedzialności czy nie, mieści się już dzisiaj w kanonie czynników decydujących o wyborze dostawcy czy partnera biznesowego.

8. Krytyczne uwagi są również odnoszone do standardów i norm. Kwestionuje się możliwość wypracowania globalnych wytycznych w normie ISO 26000. Problem polega na tym, że poddaje się pod wątpliwość, czy możliwe jest ustanowienie globalnego systemu wartości. Normy krajowe dotyczą bowiem grupy społecznej narodowej i jej wartości narodowych. Normy międzynarodowe mogą dotyczyć różnych społeczeństw narodowych i mają sens wtedy, gdy są ograniczone do wspólnych war- 
tości narodów w regionie. Normy globalne muszą więc dotyczyć wszystkich grup społeczeństw i być wyznaczone w oparciu o globalne wartości społeczne, a taki zestaw wartości społecznych nie został jeszcze znaleziony. Można mówić jedynie o pewnych elementach wspólnych.

\subsection{EMPIRYCZNA PREZENTACJA OBIEKCJI PRZEDSIĘBIORSTW TSL WZGLĘDEM SPOŁECZNEJ ODPOWIEDZIALNOŚCI}

\subsection{ZASTOSOWANE METODY BADAWCZE}

Badania stanowiły część projektu badawczego Narodowego Centrum Nauki nr 2011/01/B/HS4/05088, pod tytułem Społeczna odpowiedzialność przedsiębiorstw sektora TSL w Polsce - diagnoza i przyszłe wyzwania. Projekt był realizowany w latach $2011-2013$. Badanie było prowadzone od października 2012 do maja 2013 roku z wykorzystaniem techniki wywiadu telefonicznego wspomaganego komputerowo (CATI). Zakres geograficzny badania obejmował terytorium Rzeczpospolitej Polskiej. Badaniami objęto następującą populację: przedsiębiorstwa świadczące usługi logistyczne, transportowe i spedycyjne działające na terytorium Rzeczpospolitej Polskiej w dniu prowadzenia badania. Dla określonej na potrzeby badań populacji istniał operat losowania - wykaz przedsiębiorstw bazujący na numerach REGON. W badaniach ankietowych wzięło udział 391 przedsiębiorstw. Błąd standardowy frakcji przy poziomie ufności $\alpha=0,05$ wynosi $5 \%$.

Dobór próby odbył się z zachowaniem warunku reprezentatywności wyników z próby. Głównym celem doboru próby była możliwość uogólnienia wyników badań na całą populację badaną/generalną, z prawdopodobieństwem równym przedziałowi ufności - w przypadku przeprowadzonych badań wynoszącym 95\%. Celem zachowania wymogu reprezentatywności, próbę wyodrębniono zastosowawszy losowy dobór warstwowy - proporcjonalny. Na potrzeby badania społecznej odpowiedzialności w przedsiębiorstwach TSL populację podzielono na warstwy według takich cech, jak:

- rodzaj świadczonych usług: logistyczne, transportowe, spedycyjne;

- wielkość przedsiębiorstwa: duże, średnie, małe;

- lokalizacja siedziby przedsiębiorstwa: na podstawie podziału administracyjnego Polski;

- okres funkcjonowania na rynku;

- zasięg działania. 
Zmiennymi kontrolowanymi były rodzaj świadczonych usług i wielkość przedsiębiorstwa. W obrębie każdej warstwy dobór respondentów był dokonywany losowo.

Zarówno w Polsce, jak i na świecie, można zauważyć niedosyt opracowań, które poruszałyby zagadnienia zróżnicowania sektorowego strategii społecznej odpowiedzialności. Odczuwalny jest niedosyt ujęć empirycznych, które pokazywałyby, czy modele zachowań społecznych są różne w zależności od charakteru działalności i czy mają jakieś cechy wspólne i jaki jest ich zakres? Chęć znalezienia odpowiedzi na te pytania stała się przyczynkiem do podjęcia badań empirycznych. Jako przykład wybrano sektor TSL. W związku z tym przyjęto, że przedmiotem badań będzie diagnoza poziomu, obszarów i form działań społecznej odpowiedzialności w przedsiębiorstwach sektora TSL w Polsce, która pozwoli zbudować model lub modele zachowań społecznych polskich przedsiębiorstw TSL, a następnie umożliwi określić kierunki i rodzaje dalszych działań, mających rozwijać i doskonalić społeczną aktywność.

Aby uzyskać podbudowę teoretyczną dla badań empirycznych, postawiono następujące pytania badawcze:

P1: Jaki jest obecnie stopień rozwoju koncepcji społecznej odpowiedzialności w Polsce i na świecie?

P2: Jak należy rozumieć pojęcie społecznej odpowiedzialności?

P3: Jakie są typowe obszary działań społecznych?

P4: Jakie jest instrumentarium społecznej odpowiedzialności?

P5: Jakie są wątpliwości i uwagi wobec społecznej odpowiedzialności?

Celem głównym projektu było opracowanie modelu społecznej odpowiedzialności dla przedsiębiorstw sektora TSL wspomagającego ich działalność w rzeczywistości kreowanej przez zasady zrównoważonego rozwoju. Realizacja tak określonego celu wymagała wyszczególnienia zagadnień badawczych natury empirycznej takich, jak:

- identyfikacja obszarów społecznej odpowiedzialności w przedsiębiorstwach TSL,

- określenie pól i siły oddziaływania społecznej odpowiedzialności w przedsiębiorstwach TSL,

- identyfikacja metod i narzędzi społecznej odpowiedzialności w przedsiębiorstwach TSL,

- określenie kosztów społecznej odpowiedzialności w przedsiębiorstwach TSL,

- wskazanie ograniczeń w realizacji koncepcji społecznej odpowiedzialności w przedsiębiorstwach TSL, 
- określenie, czy występuje specyfika realizacji społecznej odpowiedzialności w przedsiębiorstwach TSL i na czym ona polega,

- identyfikacja korelacji między społecznej odpowiedzialności a efektywnością działalności przedsiębiorstw TSL,

- konceptualizacja modelowych metod i narzędzi społecznej odpowiedzialności wspomagających funkcjonowanie przedsiębiorstw TSL,

- opracowanie ścieżki i warunków wdrożenia modelu społecznej odpowiedzialności dla przedsiębiorstw TSL.

Na potrzeby badań poczyniono generalne założenie, że występuje specyfika zachowań przedsiębiorstw TSL w zakresie społecznej odpowiedzialności.

\subsection{WYBRANE WYNIKI BADAŃ}

Oceniając poziom zaawansowania wdrożenia strategii społecznej odpowiedzialności w przedsiębiorstwach sektora TSL w Polsce, wyniki badań (wykres 1) wskazują, że prawie połowa, tj. 44\%, przedsiębiorstw nie widzi potrzeby realizowania założeń społecznej odpowiedzialności. Tylko 22,6\% przedsiębiorstw potwierdziło realizację założeń społecznej odpowiedzialności, przy czym w $13,1 \%$ przypadków podejmowane działania nie mają sformalizowanej formy.

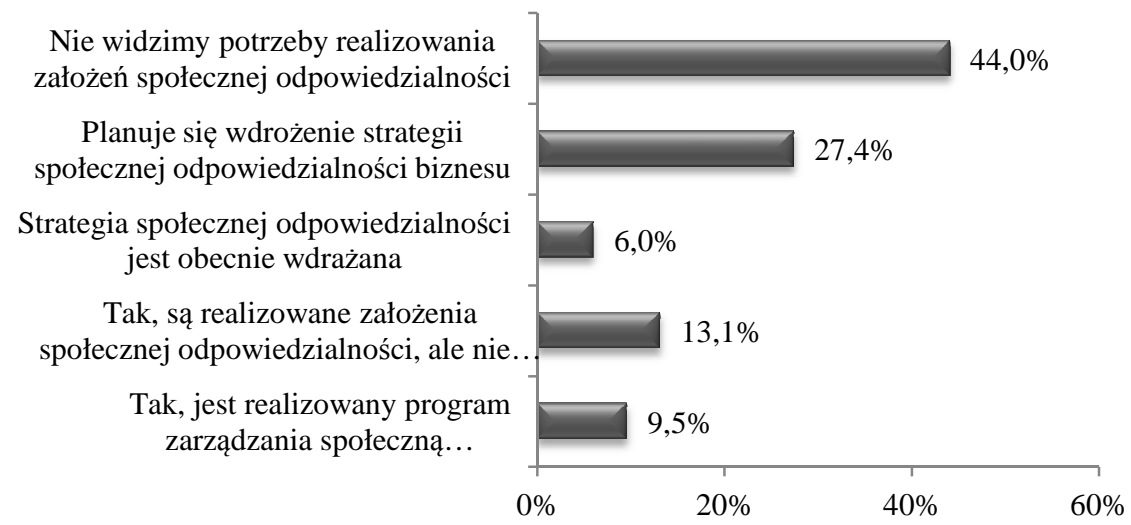

Wykres 1. Poziom zaawansowania wdrożenia strategii społecznej odpowiedzialności w przedsiębiorstwach TSL

Źródło: opracowanie własne.

Pytając o powód nierealizowania założeń społecznej odpowiedzialności (wykres 2), najwięcej przedsiębiorstw, aż 42,9\%, wskazało na to, że są zbyt małe. Innym ważnym powodem braku zainteresowania aktywnością w ob- 
szarze społecznej odpowiedzialności jest konieczność poświęcenia czasu. Na tę przyczynę wskazało $25,7 \%$ przedsiębiorstw. Równie duża grupa przedsiębiorstw, tj. 20\%, nie upatruje w społecznej odpowiedzialności korzyści. Korzyści są tutaj rozumiane ogólnie, bez wskazywania na warstwę rodzajową. Przeszkodą okazują się być także zbyt wysokie koszty działań podejmowanych w ramach społecznej odpowiedzialności. Na taka odpowiedź wskazało $8,6 \%$ przedsiębiorstw, które wcześniej zadeklarowały brak potrzeby realizowania założeń społecznej odpowiedzialności. Tylko w 2,9\% przypadkach asertywna postawa przedsiębiorstw wobec społecznej odpowiedzialności wynika z braku wiedzy, jak realizować taką strategię.

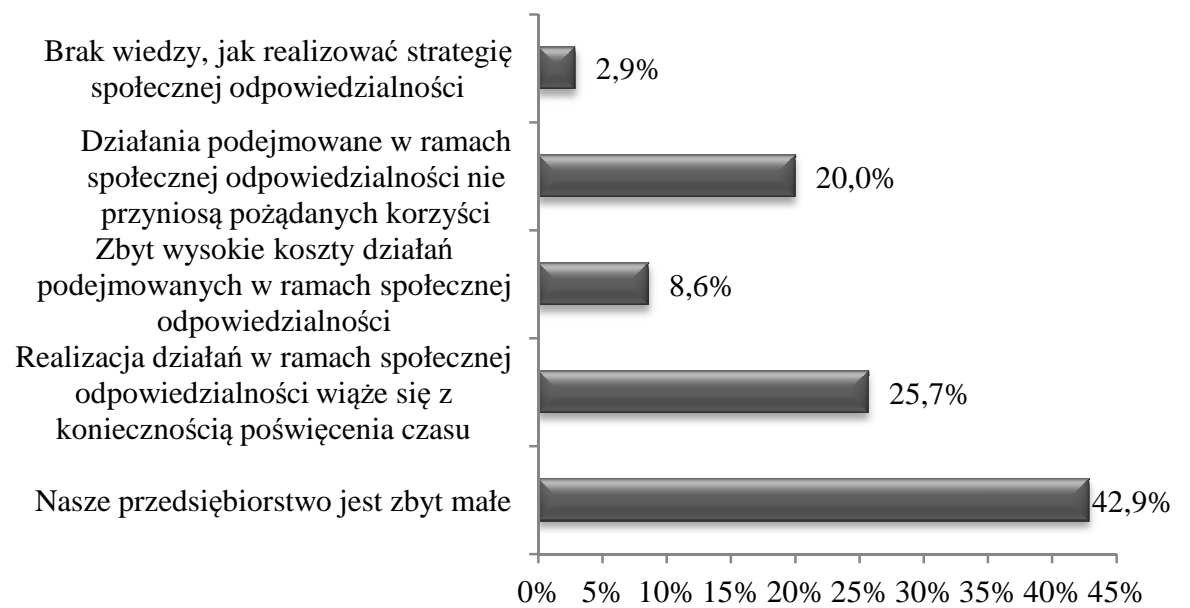

Wykres 2. Przyczyny niewdrażania strategii społecznej odpowiedzialności w przedsiębiorstwach TSL

Źródło: opracowanie własne.

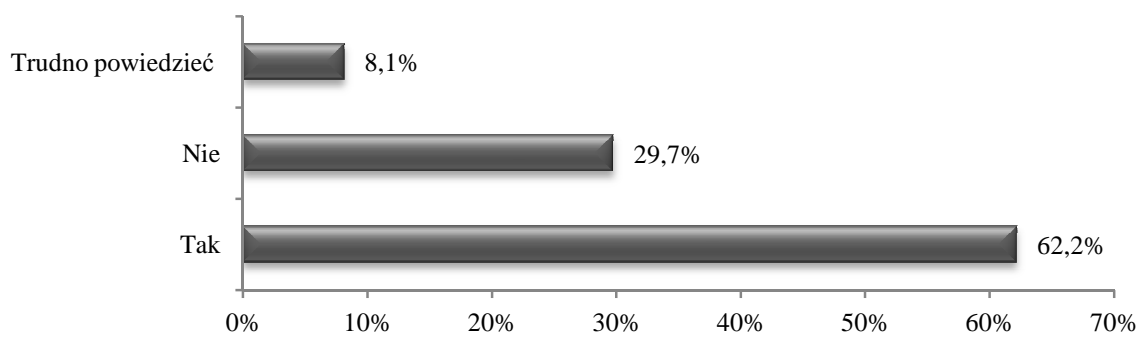

Wykres 3. Odsetek przedsiębiorstw TSL planujących wdrożenie strategii społecznej odpowiedzialności

Źródło: opracowanie własne. 


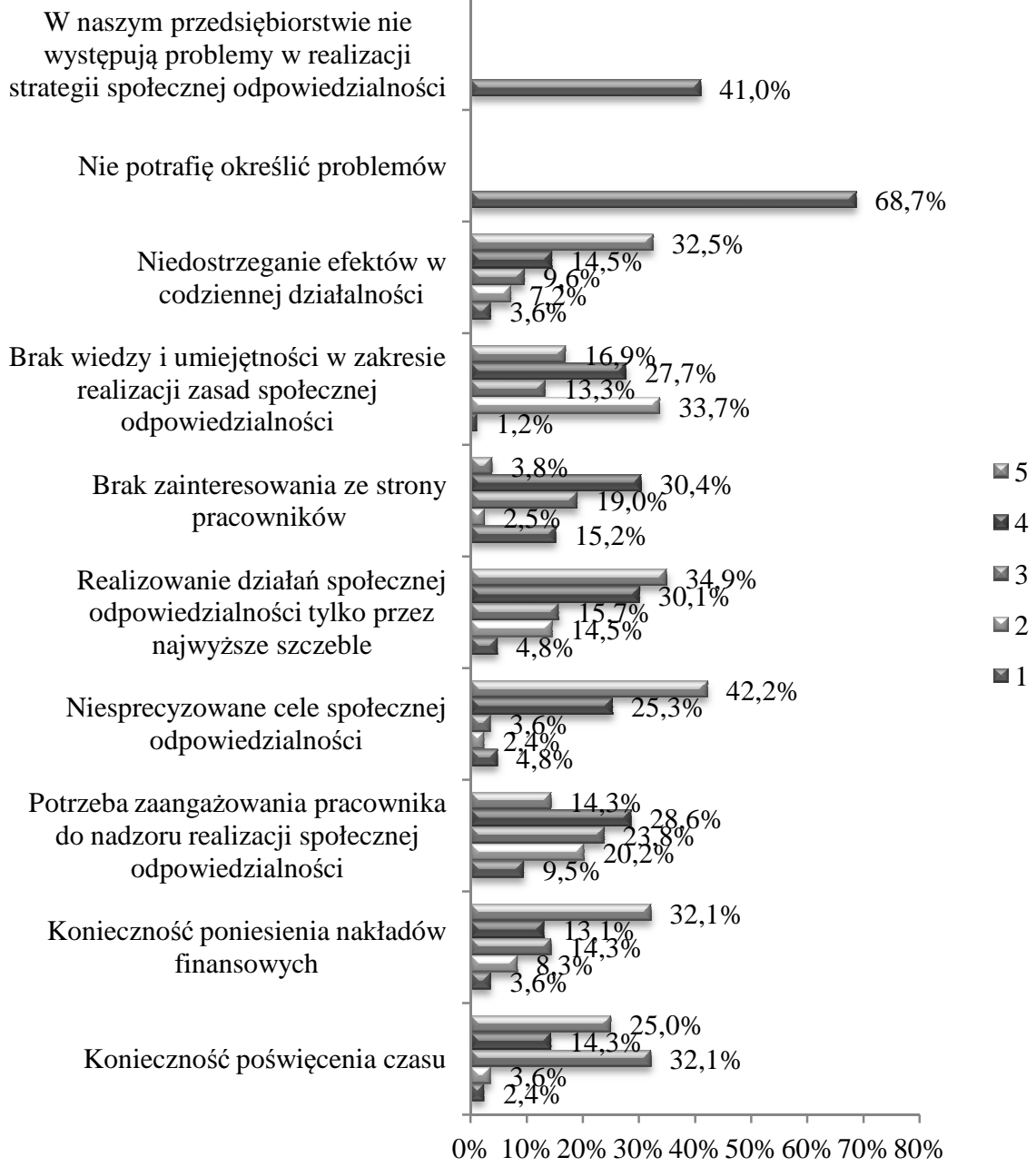

Nie potrafię określić problemów

Niedostrzeganie efektów w codziennej działalności

Brak wiedzy i umiejętności w zakresie realizacji zasad społecznej odpowiedzialności

Brak zainteresowania ze strony pracowników

Realizowanie działań społecznej odpowiedzialności tylko przez najwyższe szczeble

Niesprecyzowane cele społecznej odpowiedzialności

Potrzeba zaangażowania pracownika do nadzoru realizacji społecznej odpowiedzialności

Konieczność poniesienia nakładów finansowych

Konieczność poświęcenia czasu

$0 \% \quad 10 \% 20 \% 30 \% 40 \% 50 \% 60 \% 70 \% 80 \%$

Wykres 4. Problemy dostrzegane w przedsiębiorstwach TSL w realizacji zasad społecznej odpowiedzialności (5 - najwyższy stopień ważności)

Źródło: opracowanie własne.

W przypadku podanych wcześniej odpowiedzi trudno jednoznacznie określić, czy wskazane powody są implikacją całkowicie krytycznej postawy przedsiębiorstw wobec społecznej odpowiedzialności, czy może należy je traktować w kategorii obiekcji. Analizując dane przedstawione na wykresie 3, można przypuszczać, że w większości przypadków są to jednak obiekcje. 
Pytając bowiem, czy przedsiębiorstwa planują wdrożenie strategii społecznej odpowiedzialności ponad połowa $\mathrm{z}$ nich, czyli $62,2 \%$, odpowiedziało twierdząco. Negatywnie odniosło się do zapytania prawie $30 \%$ przedsiębiorstw. Zauważyć należy, że w tej grupie znalazły się przedsiębiorstwa, które wcześniej twierdziły przede wszystkim, że są zbyt małe, by realizować strategię społecznej odpowiedzialności, jak też, że nie widzą w takich działaniach korzyści.

Obiekcje wobec społecznej odpowiedzialności mogą się pojawiać nie tylko w przypadku przedsiębiorstw, które jej jeszcze nie wdrożyły, ale równie dobrze mogą je zgłaszać te przedsiębiorstwa, które realizują już strategię społecznej odpowiedzialności. Na pytanie, jakie najważniejsze problemy są dostrzegane w przedsiębiorstwach TSL w realizacji zasad społecznej odpowiedzialności najczęściej wymieniano: niejasno określone cele społecznej odpowiedzialności - 42,2\%, konieczność poniesienia nakładów finansowych - 32,1\%, niedostrzeganie efektów w codziennej działalności przedsiębiorstwa - 32,5\%, konieczność poświęcenia czasu - 25,0\%. Relatywnie mało istotnym problemem jest brak wiedzy i umiejętności w zakresie realizacji zasad społecznej odpowiedzialności, by je w praktyce stosować. Interesujące jest to, że aż 68,7 \% przedsiębiorstw nie potrafi określić problemów związanych z realizacją społecznej odpowiedzialności. Nie mniej ciekawy jest fakt, iż $41 \%$ przedsiębiorstw takich problemów nie zauważa u siebie.

\section{DYSKUSJA NAD POSTAWAMI PRZEDSIĘBIORSTW TSL WOBEC SPOŁECZNEJ ODPOWIEDZIALNOŚCI}

Zasadnicze pytanie, jakie nasuwa się w wyniku analizy zachowań przedsiębiorstw sektora TSL względem strategii społecznej odpowiedzialności brzmi, czy zidentyfikowane postawy są typowe dla badanej grupy przedsiębiorstw? Innymi słowy, czy są to postawy typowe dla podmiotów działających w sektorze TSL? Kolejne pytanie dotyczy przyczyn tych postaw - czy należy je traktować w sposób ogólny, czy może są specyficzne dla tego obszaru działalności gospodarczej? Uzyskanie odpowiedzi na te pytania wymaga sięgnięcia po wyniki innych badań, których warstwa problemowa jest taka sama. Uzasadnione jest, by sięgnąć do badań, w których próba losowa nie była różnicowana według rodzajów działalności, jak też do badań, prowadzonych na próbie losowej składającej się z przedsiębiorstw reprezentujących jeden rodzaj działalności gospodarczej.

Szukając odpowiedzi na pierwsze pytanie, można oprzeć się na wynikach badania przeprowadzonego przez PARP pt. „Ocena stanu wdrażania standardów społecznej odpowiedzialności biznesu”, wykonanych w 2011 roku. Dane wskazują, że 70\% przedstawicieli dużych firm zna pojęcie CSR, a 84\% 
z nich zaimplementowało strategię społecznej odpowiedzialności w swojej działalności. Gorzej sytuacja wygląda w przypadku firm mikro i małych. Znajomość pojęcia CSR zadeklarowało tylko $26 \%$ przedsiębiorstw tej grupy, a stosowanie strategii społecznej odpowiedzialności $36 \%$.

Wyniki badań przeprowadzonych w województwie mazowieckim w sektorze MŚP agrobiznesu z obszarów wiejskich (2011) potwierdzają wyniki przywołane wcześniej. Jednocześnie dają odpowiedź na drugie z postawionych pytań. Dowodzą bardzo słabej znajomości koncepcji społecznej odpowiedzialności wśród przedsiębiorców branży agrobiznesu. Ponad połowa, bo aż $60 \%$ badanych przyznało się, że nie zna pojęcia CSR. Jedynie $16 \%$ badanych przedsiębiorców potwierdziło jednoznacznie, że zasady i standardy społecznej odpowiedzialności są im znane (24\% przedsiębiorców stwierdziło, że raczej zna koncepcję CSR).

Jakie są zatem największe bariery wdrażania społecznej odpowiedzialności w małym albo średnim przedsiębiorstwie? W tym przypadku wyniki badań wykonanych $\mathrm{w}$ grupie przedsiębiorstw $\mathrm{z}$ sektora TSL pokrywają się $\mathrm{z}$ wynikami innych badań oraz z powszechnie dostępnymi opiniami. W największym stopniu przeszkodą są brak środków finansowych i brak czasu. Ważny, choć już mniej, jest brak świadomości i wiedzy z zakresu nie tyle społecznej odpowiedzialności w ogólnym ujęciu, co w zakresie jej potencjału narzędziowego i sposobów jego wykorzystania. Zauważyć również można, że przedstawiciele małych i średnich przedsiębiorstw nie mają dostatecznej wiedzy, z jakiej pomocy mogą skorzystać w zakresie wdrażania strategii społecznej odpowiedzialności, zarówno pomocy merytorycznej, jak i pomocy finansowej.

\section{WNIOSKI}

Na podstawie rozważań przedstawionych w opracowaniu można sformułować ogólne wnioski:

1. Sposób rozumienia społecznej odpowiedzialności wpływa na to, jak jest ona traktowana $\mathrm{w}$ sferze nie tylko poznawczej, ale również w emocjonalnej. To z kolei kształtuje formy i kierunki zachowań przedsiębiorców wobec niej.

2. Im większy jest poziom świadomości w zakresie społecznej odpowiedzialności, tym bardziej sformalizowaną formę przybierają działania w jej poszczególnych obszarach, jak też są one bardziej zintegrowane obszarowo.

3. W sektorze TSL społeczna odpowiedzialność jeszcze nie jest popularną strategią, choć istnieją podstawy, by twierdzić, że strategia ta będzie sukcesywnie wdrażana przez coraz większą liczbę przedsiębiorstw. Wi- 
dać wyraźny podział na przedsiębiorstwa duże, o mocnej pozycji na rynku, które w sposób świadomy realizują strategię społecznej odpowiedzialności, i przedsiębiorstwa małe i średnie, które widzą potrzeby, by taka strategię wdrożyć.

4. Postawy MSP w sektorze TSL nie odbiegają od postaw MSP w innych branżach. Są również podobne do postaw, jakie można obserwować w innych krajach europejskich, co znaczy że problem słabej aktywności MSP nie jest problemem tylko naszego kraju, jest osadzony na poziomie Unii Europejskiej.

Pojawiają się także pewne wątpliwości dla kolejnych dyskusji:

1. Aby pobudzić aktywność małych i średnich przedsiębiorstw w zakresie działań CSR, niezależnie od branży, należy szukać odpowiedzi na pytania - w jaki sposób zachęcić MSP do wdrożenia strategii społecznej odpowiedzialności, jakimi instrumentami ich aktywność skutecznie pobudzać, kto powinien być za to odpowiedzialny?

2. Można się zastanawiać, czy może zachowanie MSP jest prawidłowe. Może społeczna odpowiedzialność, z natury rzeczy, powinna być zarezerwowana dla dużych przedsiębiorstw? Może przedstawiciele MSP mają rację, uważając, że strategia społecznej odpowiedzialności nie przyniesie ich działalności korzyści i jakkolwiek nie warto w nią inwestować.

\section{LITERATURA}

Basu K., Palazzo G. (2008), Corporate Social Responsibility: A Process Model of Sensemaking, ,Academy of Management Review”, 33(1), 122-136, DOI: 10.5465/AMR.2008.27745504.

Boiral O. (2007), Corporate Greening Through ISO 14001: A Rational Myth?, „Organization Science" 18(1), 127-146, DOI: 10.1287/orsc.1060.0224.

Crook C. (2005), A Survey of Corporate Social Responsibility, „The Economist”, January 22.

Dembińska I. (2014), Społeczna odpowiedzialność w przedsiębiorstwach sektora TSL: analiza postaw w świetle badań, „Logistyka”, 5, 1773-1785.

Fleming P., Jones M. T. (2013), The End of Corporate Social Responsibility, Crisis and Critique, Sage Publications, London.

Friedman M. (1970), The social responsibility of business is to increase its profits, „The New York Times Magazine", September 13.

Friedman M. (2002), Capitalism and Freedom, University Of Chicago Press, Chicago.

Henderson D. (2001), Misguided Virtue: False Notions of Social Corporate Social Responsibility, New Zealand Business, Roundtable, June.

Karnani A. (2010), The Case Against Corporate Social Responsibility, „Wall Street Journal”, August 23.

Khan F. R., Munir K. A., Willmott, H. (2007), A Dark Side of Institutional Entrepreneurship: Soccer Balls, Child Labour and Postcolonial Impoverishment, „Organization Studies”, 28(7), 1055-1077, DOI: 10.1177/0170840607078114. 
Laufer W. S. (2003), Social Accountability and Corporate Greenwashing, „Journal of Business Ethics", 43(3), 253-261, DOI: 10.1023/A:1022962719299.

Ocena stanu wdrażania standardów spotecznej odpowiedzialności biznesu. Raport PARP, Warszawa, 9 grudnia 2011. Raport dostępny na:

http://www.ewaluacja.gov.pl/Wyniki/Documents/Ocena_stanu_wdrazania_standardo w_spolecznej_odpowiedzialnosci_biznesu_13022013.pdf

Roberts J. (2003), The Manufacture of Corporate Social Responsibility: Constructing Corporate Sensibility," Organization", 10(2), 249-265, DOI: $10.1177 / 1350508403010002004$.

Rok B. (2013), Podstawy odpowiedzialności społecznej w zarzadzaniu, Poltext, Warszawa.

Sims R. R., Brinkmann J. (2003), Enron ethics (Culture matters more than codes), „Journal of Business Ethics", 45(3), 243-256, DOI: 10.1023/A:1024194519384.

Sternberg E. (1994), Just Business, Little Brown, London, w.: Sparks R. (2003), A Pragmatic Approach to CSR, School of Management, The London School of Economic, 19 May.

Wołoszyn J., Stawicka E., Ratajczak M. (2011), Społeczna odpowiedzialność matych i średnich przedsiębiorstw agrobiznesu z obszarów wiejskich, Wydawnictwo SGGW, Warszawa.

\section{DOUBTS AND CRITICAL ATTITUDES OF THE TSL COMPANIES CONCERNING THE USE OF SOCIAL RESPONSIBILITY PRINCIPLES BASED ON THE RESULTS OF EMPIRICAL RESEARCH}

A b s t r a c t. The article discusses the issues of doubts and critical attitude of companies concerning corporate social responsibility based on the example of companies in the TSL sector. This article is divided into two main parts. In the first part the literature review within the problem in question has been presented. The aim of this part was to show the doubts and critical remarks with regard to social responsibility. In the second part the results of empirical studies were cited as a basis for determining the reasons for objections to the corporate social responsibility among companies in the TSL sector.

K e y w o r d s: corporate responsibility, ethics, sector TSL. 